\title{
Public Attitudes Towards Multiculturalism and Interculturalism in Australia
}

\author{
Amanuel Elias $^{1}$ (D) $\cdot$ Fethi Mansouri $^{1} \cdot$ Reem Sweid $^{1}$ \\ Accepted: 22 September 2020/Published online: 6 October 2020 \\ (C) The Author(s) 2020
}

\begin{abstract}
The growing intellectual and policy debate around optimal approaches to diversity governance, particularly in relation to criticism of multiculturalism, is now entering a new phase characterised by advocating alternative conceptual and policy paradigms most notably interculturalism. Proposing a conceptual complementarity approach, rather than dogmatically oppositional stances, this paper approaches interculturalism as offering heuristic additive values to multiculturalism. As the paper shows, the Australian context indeed offers an optimal case study for conceptualising and engaging with interculturalism within an otherwise resilient multicultural framework. Australia's unique and strong multicultural ethos has combined with successful intercultural strategies at different levels of diversity governance, policy and practice across various sectoral terrains. This paper uses an online national survey to examine the public understanding of and attitudes towards multiculturalism and interculturalism as supposedly distinct yet interconnected policy tools relating to the ever-changing diversity governance agenda.
\end{abstract}

Keywords Multiculturalism · Interculturalism · Intercultural dialogue $\cdot$ Migration $\cdot$ Cultural diversity · Australia

\section{Introduction}

Australia is often invoked as a successful multicultural country with a long history of welcoming and settling migrants from all corners of the world (Ang and Stratton 1998; Colic-Peisker 2011; Mansouri 2015). Whereas Europe and North America are witnessing growing contestation regarding the efficacy of political multiculturalism, with critics proposing interculturalism as an

Amanuel Elias

amanuel.h@deakin.edu.au

1 Alfred Deakin Institute for Citizenship \& Globalisation, Deakin University, 221 Burwood HWY, Burwood, VIC 3125, Australia 
alternative diversity governance approach, such a polarising and impassioned debate is not widely prevalent in Australia (Levey 2018a). Rather, multiculturalism has enjoyed and continues to enjoy support in public discourse, with intercultural initiatives being understood and accepted within the broader context of a multicultural framework (Koleth 2010; Liddicoat 2009). The distinction between the European and Australian perspectives on the multiculturalism/ interculturalism debate reflects the different socio-historical origins of multiculturalism in these continents. For example, multiculturalism in the UK is recognised mainly as a demographic fact; in Sweden ethnic diversity policy tends to be geared more towards interculturalism; whereas in France and Germany there are no official policies and ideologies proactively supporting and enacting multiculturalism (Banting and Kymlicka 2013).

Owing to its unique immigration history, the evolution of official multiculturalism in Australia is, indeed, quite different from the British integrationist version, and the Canadian and New Zealand versions that are based on national minority cultural preservation (Levey 2012, 2018a; Meer and Modood 2012; Modood 2011). Thus, many of the criticisms levelled against multiculturalism globally are perhaps less relevant to the Australian ethno-cultural context where there has been neither a fierce backlash against it nor a strong gravitation towards an alternative paradigm. On the contrary, multiculturalism has endured as an essential part of the country's self-expressed national identity (Markus 2016, 2017) albeit with persistent challenges around the social integration of particular groups and the more securitised agendas of post 9/11 socio-political national context (Mansouri 2015). More interestingly - and in sharp contrast to the situation in Europe-interculturalism and particularly intercultural dialogue (ICD) has been introduced across various Australian settings, most notably education and city councils (Blair 2015; Walton et al. 2013). Furthermore, public discussions regarding migration and intercultural relations have largely steered away from a contested juxtaposition that presents multiculturalism and interculturalism as mutually exclusive paradigms, as has been the case in other Western countries (Blair 2015). The Australian context can therefore offer a unique perspective to the ongoing global debate, arguing for the framing of multiculturalism and interculturalism as complementary approaches for successful diversity governance rather than as competing, mutually exclusive approaches.

To this end, this paper engages with some of the core theoretical foundations of the two concepts, offering some comparative perspectives on the historical evolution of multiculturalism in Europe, North America and Australia. It then presents the current study in order to elucidate the potential significance of the Australian case to the wider global discussion around these two concepts. Although there have been numerous public statements and discussions of a reported backlash against multiculturalism in many countries, it has not been empirically possible to ascertain if such a discourse correctly reflects the actual multicultural conditions in the various countries (Dei 2011; Modood and Meer 2012; Però 2013; Meer et al. 2016; Kymlicka 2012; Triandafyllidou 2012). Based on nuanced empirical analysis of public attitudes towards current policy approaches to diversity governance, this paper aims to contribute to this growing debate from the distinct contextual situation that characterises the Australian case study. 


\section{Multiculturalism and Interculturalism}

Political theorising around multiculturalism was initially concerned with the recognition of minority cultural rights within institutions of liberal democracy (Taylor 1994; Kymlicka 1995; Parekh 2000). Charles Taylor's (1994) influential work on multiculturalism advanced the idea of "recognising" the cultural claims of minority groups, which has since been associated with and affected by the modern politics of identity. Then, as now, multiculturalism was commonly associated with ideas of tolerance, recognition and accommodation of minority rights (Arsaratnam 2013; Vertovec 2010). Notwithstanding the problematic assumptions underpinning notions of tolerance and accommodation, overall, multiculturalism represents a positive vision of an inclusive plural society that supports minority groups based on "equality and sense of belonging" encapsulated in the idea of multicultural citizenship (Modood 2011, p. 18; Parekh 2000). As such, its pursuit of equality and the recognition of the rights of ethnically, racially or religiously diverse groups represent some of its most intrinsic features (Joppke 1996). Today, multiculturalism is understood as "the political accommodation by the state and/or a dominant group of all minority cultures defined first and foremost by reference to race, ethnicity or religion" (Meer and Modood 2012, p. 181).

Multiculturalism, as a migration and diversity policy tool in Western societies, was advanced in the 1970 s on the back of the emancipatory socio-political movements of the period (Syed and Kramar 2009; Parekh 2000; Modood 2007; Vertovec 2010). Pointing to its evolution over four decades of social transformation, Kymlicka (2012, p. 6) depicts it as an integral "part of a larger humanrights revolution involving ethnic and racial diversity". Multiculturalism was espoused as the optimal policy paradigm to overcome the shortcomings of assimilationist policies of the pre-Civil Rights era (Kymlicka 2012). In the decades that followed the Civil Rights movement, many Western émigré societies witnessed a gradual shift away from exclusionary ideologies towards more egalitarian approaches to social policies that emphasised minority rights and cultural diversity (Kymlicka 2012; Mansouri 2015). Multiculturalism was one such policy framework adopted in traditionally immigrant countries such as Canada, Australia, the UK and the USA (Freeman 2004). However, each country's brand of multiculturalism varied depending on the history of its immigration experience and the status of its indigenous peoples, even though the inherent values of equality and recognition of minorities remained essentially universal across all jurisdictions (Castles 2002; Castles and Miller 2003).

Over the last two decades and in particular since the terrorist events of $9 / 11$, dissatisfactions with political multiculturalism have intensified as new security concerns have come to be intrinsically linked with growing diversity and failed multicultural policies (Hassan and Martin 2015; Michalski 2006). This situation has gradually led to a more negative diversity discourse very much critical of all things multicultural. In Europe, former UK Prime Minister David Cameron, German Chancellor Angela Merkel and former French President Nicolas Sarkozy, for example, made critical statements about multiculturalism blaming it for problems related to lack of social integration of migrants and a weakening national security. The overarching argument has been that multiculturalism has failed as a social policy and created segregated societies along cultural and 
religious lines in a manner that is inconsistent with "Western" liberal values (Dei 2011; Però 2013). This, along with a more salient academic debate regarding the adequacy of multiculturalism, brought to the fore arguments for alternative, more "muscular" policy approaches that can ensure stronger social cohesion within hyper-securitised global and local contexts. This alternative approach was supposed to mitigate the alleged failures of multiculturalism, including its inability to prevent social division and intercultural disharmony (Barry 2001; Vertovec 2010; May and Sleeter 2010). Scholars (e.g. AbdallahPretceille 2006; Cantle 2012; Zapata-Barrero 2015) have emphasised the need for an alternative intercultural approach that de-emphasises ethno-religious affiliations and cultural differences, and de-essentialises cultural minorities.

In addition to emergent security concerns, interculturalism was also characterised as more in tune with super-diversity - a phenomenon reflecting complex socio-cultural expressions of identity and attachments (Rodríguez-García 2010; Vertovec 2007; Zapata-Barrero 2017). It is understood as a contact-based approach to diversity management that emphasises intergroup interaction, exchange and dialogue (ZapataBarrero 2019). In this context, interculturalism is hailed as a new concept distinct from multiculturalism and focussed on harnessing intercultural understanding and social harmony in an increasingly super-diverse globalised world (Cantle 2012). Its fundamental features include a focus on intercultural contact, meaningful exchange between individuals of different socio-cultural backgrounds and attachment to shared national values. Interculturalism is, therefore, seen as containing the epistemological tools necessary for achieving at once national security and social cohesion, two policy objectives that are alleged to have eluded multiculturalism (Cantle 2012).

Interculturalism is not a completely new approach but predates the current diversity management debate and has arisen before it "was formulated a decade or so ago into the European version largely addressed in Western scholarship" (Elias and Mansouri 2020: 2; Zapata-Barrero 2017). Interculturalism as articulated in various countries in Europe (UK, Sweden, Spain, etc.), Canada and Australia vary, depending on the local historical contexts (Levrau 2018). The contemporary version of interculturalism also varies in interpretations and approaches with the post-colonial Latin American version interculturalidad that has long existed in education (Solano-Campos 2013). The version discussed in this paper as promoted in the early 1980s (Council of Europe 2008; Modood 2011) has emerged as a potential diversity policy in Canada, to maintain Québécois national identity (Bouchard and Taylor 2008; Zapata-Barrero 2017). Currently, interculturalism has gained more international attention in migrant integration scholarship and diversity governance circles. The release of the 2008 Council of Europe White Paper has particularly accelerated interest on this intercultural approach (Council of Europe 2008; Delany-Barmann 2010; Zapata-Barrero 2017).

However, interculturalism as currently espoused rests on a problematic polemical mischaracterisation of multiculturalism (Modood 2017; Joppke 2017) that does not reflect its historical development nor its contemporary manifestation across different jurisdictions (Mansouri 2015). Steering away from ideological polarisation, this paper discusses the Australian situation, which provides a pathway for possible complementary rather than substitutive relationship thus yielding an overall revitalised diversity agenda (Mansouri 2015; Modood 2017). 


\section{Multiculturalism in Australia}

Multiculturalism was introduced in Australia in the 1970s to replace earlier assimilationist approaches to diversity governance, at a time when ethnic and cultural diversity started to increase with new waves of immigration (Koleth 2010; Ang and Stratton 1998). Until then, the Australian government had pursued deliberately and carefully planned - under the Immigration Restriction Act of 1901—restrictive immigration policies that came to be known as the White Australia Policy (Jupp 2002). In addition to restricting migrant intake to predominantly Anglo-Celtic Europeans, the assimilationist policies led to the marginalisation of non-European migrants and the exclusion of Indigenous people socially, culturally and economically (Jupp 2002). In the 1960s, this exclusionary policy, which was openly racist and discriminatory, became increasingly indefensible with the Liberal Holt Government (1966-1967) starting to shift towards a more inclusive, pluralistic social policy. Later, under the Labour Whitlam Government (1972-1975) and subsequent Liberal Fraser government, Australia embraced multiculturalism as formal policy with bipartisan support. Indeed, political leaders from both sides of the political aisle and senior public figures frequently proclaim Australia a successful multicultural society, despite immigration issues, racism and discrimination continuing to generate intense public debate, especially during times of political upheaval and economic difficulties (Ang and Stratton 1998; Markus 2016).

In justifying Australia's adoption of multiculturalism, political leaders often stress the socio-economic benefits it can provide. First, multiculturalism as a migrant settlement policy tool has the capacity to manage the growing diversity characterising Australian society. Second, it can function as an anti-racism strategy that can eliminate racial discrimination and ensure social justice. Third, in relation to the grand objective of ensuring cohesive national identity, it can ensure unity in diversity through a commitment to Australian national identity and a sense of shared values. Finally, it offers significant economic opportunity by tapping into the underutilised skills potential of migrants (Ho 1990).

Yet over the years, Australian multiculturalism has been framed mainly around the broader societal acceptance of the cultural rights of minority groups within mainstream society (Mansouri 2015; Koleth 2010). Its basic tenets, predicated on the equality of rights and opportunities for everyone regardless of ethnic backgrounds, have remained an enduring feature across successive governments and policy articulations. Thus, in its current form, Australian multiculturalism encompasses the acceptance of ethnic and cultural diversity, inclusive immigration policies and legislations prohibiting racial discrimination (Ho 1990; Koleth 2010). It has been viewed as an integral component of the Australian national identity, which emphasises normatively the overarching goal of achieving a just society that is inclusive of culturally diverse groups (Levey 2012). Successive Australian Labour and Liberal governments have deployed multiculturalism in this normative sense, formulating a range of social policies, such as "the pursuit of social justice, the recognition of identities and appreciation of diversity, the integration of migrants, nation building, and attempts to achieve and maintain social cohesion" (Koleth 2010, p. 2).

Perhaps it is because of this de-politicised approach to diversity governance that Australian multiculturalism still enjoys broad-based public support although there remain 
different interpretations of its exact meaning in light of emerging global trends relating to human mobility, super-diversity and security concerns (Castles 2002; Mansouri 2015; Liddicoat 2009). With its emphasis on shared values, national citizenship and the rule of law, Australian multiculturalism is still regarded as an economically and socially vital policy strengthening the national interest (Levey 2012). This is in contrast to how multiculturalism has been portrayed in Europe and North America in recent years (Levey 2012, 2018a), with public proclamations of the "failure of multiculturalism" and the "backlash against multiculturalism" continuing to shape public debates.

This Australian exception described above becomes even more ostensible in the ongoing multiculturalist/interculturalist debate underway in Europe, Canada and the UK. Indeed, interculturalism has been promoted in some European policy circles as an alternative governance paradigm to multiculturalism (Zapata-Barrero 2017). This is despite the claims of multiculturalism proponents that it lacks normative substance and conceptual distinctiveness to offer a genuine alternative paradigm (Modood 2017). Rather than being stuck in a sterile debate about interculturalism being substitutive to multiculturalism, this paper argues that historical and contemporary empirical evidence shows that a complementary approach is possible, indeed desirable (Mansouri et al. 2017). In the Australian context, multiculturalism and intercultural practices often operate in tandem, rather than as a mutually exclusive set of policies (Blair 2015; Liddicoat 2009). Australia's multicultural policy integrates cultural rights, including the retention of heritage culture and language, along with what can be seen as intercultural ideals, such as meaningful exchanges, cross-cultural literacy approaches and an attachment to core Australian values, for example, regarding gender equality, rule of law and democracy. The ultimate goal within such an approach is achieving a "pluralist society that is open to multiple influences within the limits imposed by the respect for fundamental democratic values and the need for intergroup exchange" (Delafenetre 1997, p. 92; Levey 2012).

Currently, Australian multiculturalism is yet to be legislated at the national level. However, states (e.g. Victoria, New South Wales and Western Australia) have legislated multicultural acts, with various provisions of rights and recognitions of diversity. This indicates some degree of overlap in policy legislation and implementation. Across different levels of government, available multicultural policy incorporates specifically the provision of access to government programs and services, equity in the delivery of outcomes for diverse communities and protection against discrimination. These goals laid out in various policy documents (e.g. Multicultural Policy Statement, The Peoples of Australia, Multicultural Access and Equity Policy) seek to achieve social integration through immigrant settlement programs, support services, language programs and cultural heritage recognition.

Compared with multicultural policy, interculturalism has not taken hold in Australia as firmly as it has in Europe and Canada. Intercultural practice, which by definition is more about contact, dialogue, interaction and exchange involving individuals from different cultures occurs, mainly occurs within local settings - such as schools, among neighbourhood communities and in local councils. The stated goal of an intercultural approach is to foster social cohesion. This has been the alleged weaken of Australian multiculturalism that it has not gained currency within mainstream society. Yet, it has also been argued that in Australia, multiculturalism encompasses features that would normally be considered elements of interculturalism-e.g. respect, understanding and 
shared values (Levey 2018b). This leads to the argument that multiculturalism could promote rather than inhibit intercultural dialogue, which is as much an empirical as it is a theoretical question.

\section{Methods}

\section{Data}

The data for this paper are drawn from a national Australian survey, the Survey of Views on Multiculturalism and Interculturalism (SVMI), conducted as part of a larger project on diversity governance in Victoria. The SVMI was designed to investigate public perceptions of and sentiments towards multicultural and intercultural issues. Respondents reflected on their understandings of the concepts of multiculturalism, interculturalism and ICD; how these relate to one another; and how each and/or a combination can affect the future of cultural diversity and social cohesion.

The survey was conducted through Survey Sampling International (SSI), an online data service provider that curates a global sample of potential respondents. This sample is drawn from a large non-probability panel of Australian respondents. Specifically, SSI continuously upgrades its panel and attempts to ensure data quality by recruiting participants from across partnership sources. Participants were selected from a large and diverse sampling pool, and risk of bias was minimised via a multi-stage randomisation process. Participants were recruited either by being randomly selected from existing SSI panels or by responding to an online message. After answering randomly selected, non-leading profiling questions, participants are randomly matched with the survey they are likely to complete. SSI recruits participants via multiple platforms including email, telephone alerts, messaging and online banner advertising. Messages from SSI to potential respondents often vary from an invitation to provide views, win prizes, earn money or voice opinions, which capture a variety of motivations to participate. Self-selection bias is minimised by not disclosing project-specific details. Once participants have agreed to respond to the survey, the project description is disclosed to them ${ }^{1}$.

Data was collected between 26 April 2017 and 3 May 2017 with the survey taking an average of $6.24 \mathrm{~min}$ to complete. Before commencing large-scale data collection, the survey was piloted by SSI on a sample of 60 randomly selected participants. Following a review of the pilot data by the investigators, the survey was modified before being launched online. The researchers manually examined the raw data further before coding and conducting the statistical analysis.

\section{Measures}

The survey included 13 questions on interculturalism, multiculturalism and intercultural dialogue (ICD). Details on demographic characteristics including gender, age, education, income, employment and migration status were also collected. Two open-

\footnotetext{
${ }^{1}$ More on the sampling procedure can be found in the SSI website (https://www.surveysampling.com/site/ assets/files/1069/esomar-28-questions.pdf.)
} 
ended questions asked the respondents to provide their understanding of multiculturalism and interculturalism: "what does multiculturalism/interculturalism mean to you?" The next nine questions asked them to reflect on their views on cultural diversity and the policies designed to manage it. Each question provided a seven-point Likert scale option where " 1 " indicated strong disagreement and " 7 " strong agreement. The last two questions were open-ended and asked respondents to provide their suggestions on the key challenges and opportunities related to ICD as a policy framework.

\section{Participants}

Table 1 provides a summary of the sampling distribution from the online survey completed by 1004 randomly selected respondents aged 18 years and over. Demographically, the respondents were balanced in terms of gender distribution and - for a non-probability sample - were largely comparable to the 2016 Australian Census. The age distribution in the sample was roughly consistent with the census data, with the exception of those aged 35-44 years (16.5\% in the census and $18.1 \%$ in the current sample; Australian Bureau of Statistics 2017). However, as would be expected in an online sample, people with higher levels of education (tertiary education certificate or above) were overrepresented (65.5\% vs. $46.6 \%$ according to the census; Australian Bureau of Statistics 2017). Column 1 of Table 1 reports descriptive statistics using weights to adjust for the imbalance in the sample.

Another key feature of the SVMI sample relates to migration status. Although $19.2 \%$ of the sample were migrants, respondents from a non-English speaking background (NESB) were $13 \%$ of the total. Migrants were slightly under-represented compared with the national census where more than $26 \%$ were born overseas and roughly, of which $18 \%$ were from a NESB (Australian Bureau of Statistics 2017). ${ }^{2}$

\section{Analysis}

Each question in the study required an assessment of a particular aspect of the state of cultural diversity, multiculturalism or interculturalism in policy and practice, as well as exploring respondents' broad understanding of ICD. Data analysis was based on individual response frequency and percentages. Before finalising the descriptive analysis, responses for each of the open-ended questions were analysed for relevance and coded thematically in a spreadsheet. Responses were then categorised accordingly and tabulated, with bar charts reported for questions with Likert scale responses. Finally, some key findings were analysed and discussed in light of the demographic distribution of the responses. Weights were applied during data analysis to adjust for disproportions associated with the non-probability nature of the online sample. All data was analysed using Stata software, and the key emerging findings were discussed in relation to other research.

\footnotetext{
${ }^{2}$ Based on the 2016 Census of Population and Housing, assuming an English-speaking countries list including Australia, Canada, Ireland, New Zealand, South Africa, the UK and the USA
} 
Table 1 Demographic characteristics of respondents to the Survey of Views on Multiculturalism and Interculturalism

\begin{tabular}{|c|c|c|c|c|c|}
\hline \multirow[t]{2}{*}{ Description } & \multicolumn{2}{|l|}{ Percent } & \multirow[t]{2}{*}{ Description } & \multicolumn{2}{|l|}{ Percent } \\
\hline & Unweighted & Weighted & & Unweighted & Weighted \\
\hline Observations (n) & 1004 & & & & \\
\hline Gender (male) & 50.5 & 51.6 & Highest education & & \\
\hline Age (years) & & & Did not finish year 12 at school & 15.0 & 24.4 \\
\hline $18-24$ & 12.0 & 12.3 & Finished year 12 at school & 17.3 & 16.1 \\
\hline $25-34$ & 18.2 & 15.4 & Certificate or diploma & 33.8 & 25.4 \\
\hline $35-44$ & 19.8 & 18.1 & Bachelor degree and above & 31.7 & 22.6 \\
\hline $45-54$ & 18.0 & 17 & Other and non-response & 2.2 & 11.5 \\
\hline $55-64$ & 14.8 & 15.7 & Employment status & & \\
\hline 65 and over & 17.1 & 21.4 & Employed & 50.9 & 54.4 \\
\hline Cultural background & & & Unemployed & 8.5 & 8.9 \\
\hline $\begin{array}{l}\text { Non-English } \\
\text { speaking }\end{array}$ & 15.3 & 13 & Other & 40.6 & 45.7 \\
\hline Anglo-Celtic & 33.1 & 31.4 & Income (annual) & & \\
\hline White (other) & 51.6 & 55.6 & Below $\$ 50,000$ & 38.2 & 42.2 \\
\hline Migration status & & & $\$ 50,000-99,000$ & 38.3 & 38.3 \\
\hline Migrant & 20.3 & 19.2 & $\$ 100,000-199,000$ & 20.3 & 17 \\
\hline Non-migrant & 79.7 & 80.8 & More than $\$ 200,000$ & 3.3 & 2.6 \\
\hline Schooling years & & & Multicultural leadership role & 8.9 & 9.1 \\
\hline Mean & 7.9 & 8.2 & & & \\
\hline Standard deviation & 5.9 & 5.5 & & & \\
\hline
\end{tabular}

Source: Mansouri et al. (2017). Percentages may not add up due to rounding to one decimal place

\section{Key Findings}

Data analysis of the SVMI indicated mixed and at times surprising results in terms of public understanding of multicultural and intercultural issues. Overall, most survey respondents understood multiculturalism as a state of social harmony between various cultures. However, the survey also identified a distinct lack of clarity around the meaning and ethos of multiculturalism among the general public. Reports from other studies and surveys indicate that a sizeable majority of Australians view multiculturalism as a positive force for society (Markus 2016) while also needing refocusing and reinvigoration. This positive view is consistent with the overall findings of the SVMI, which on top of this found some confusion around the distinction between multiculturalism and interculturalism. Despite a lack of clear understanding of interculturalism as a conceptual framework, with some clarification of the survey questions, SVMI respondents expressed some level of support for an intercultural dimension to managing diversity and agreed that ICD could play a potentially positive role in reinvigorating the broader multicultural agenda. 


\section{Understanding and Appraising Multiculturalism}

Figure 1 reports a summary of what multiculturalism means to respondents. The data showed that there is broad public support for multiculturalism, with almost two-thirds $(63 \%)$ of the respondents viewing multiculturalism as a given reality, while some respondents $(17.1 \%)$ understand it purely in terms of policy and practice. Nearly $51.2 \%$ of the respondents understood multiculturalism as something synonymous with cultural diversity, describing it as a mix of different cultures in a society. Roughly, 9\% emphasised the features of respect and acceptance as key aspects of multiculturalism, and only a small group (4.1\%) identified and associated it exclusively with minority groups. This slightly contrasts with Mansouri et al. (2017) who report more nuanced understanding of multiculturalism among those directly engaged in the multiculturalism sector.

Identification of multiculturalism as matter-of-fact reality characterised by ethnic and cultural diversity in the community emerged as a key finding from this study. Nearly $67 \%$ of survey respondents considered cultural diversity a fundamental feature of Australian society (Table 2). Compared with non-Anglo white Australians (64\%), Anglo-Celtic and NESB respondents expressed the largest positive perception (70\% each). Overall, however, our finding is consistent with other studies, particularly the

A number of nationalities \& cultures existing together

Many different cultures

Respect and acceptance of different cultures

A mixture of cultures, ethnic groups, peoples

Coexistence of different cultures in harmony

Cultural diversity

A society made up of people from diverse cultural backgrounds

Many different cultures in one place

People from minority cultural background

Miscellanious definitions

Non response
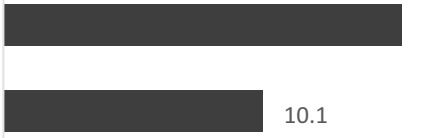

10.1

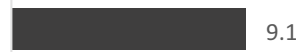

9.1

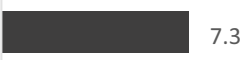

7.3

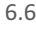

5.4

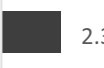

2.3

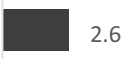

2.6

4.1

Note: $\mathrm{N}=1004$. Values indicate the proportion of responses to the open-ended question "What does multiculturalism mean to you?"

Fig. 1 Description of multiculturalism by Australian respondents. Note: $N=1004$. Values indicate the proportion of responses to the open-ended question "What does multiculturalism mean to you?" 
Table 2 Public understanding of multicultural and intercultural issues in Australia

\begin{tabular}{llll}
\hline Description & Disagree & Agree & Neutral \\
\hline Cultural diversity fundamental Australian characteristic & & & \\
Overall & 14.7 & 66.7 & 18.6 \\
NESB & 12.2 & 70.1 & 17.7 \\
Anglo-Celtic White & 11.9 & 70.4 & 17.6 \\
White (Other) & 16.9 & 63.7 & 19.4 \\
Australia successful multicultural society & & & \\
Overall & 17.4 & 63.1 & 19.5 \\
NESB & 14.1 & 60.4 & 25.6 \\
Anglo-Celtic White & 18 & 61.1 & 20.9 \\
White (Other) & 17.8 & 64.8 & 17.4 \\
Challenges in implementing effective ICD strategy ${ }^{a}$ & & & \\
Resources and training & 39.3 & 60.7 & - \\
Political leadership & 41.6 & 58.4 & - \\
Clarity of ICD policy articulations & 57.2 & 42.8 & - \\
Other challenges & 92.6 & 7.4 & - \\
Critical requirements for successful ICD & & & \\
Individual embrace (people-to-people contact) & 35.6 & 64.4 & - \\
Inclusive majority and minority participation & 37.1 & 62.9 & - \\
Local support (not just top-down directives) & 42.1 & 57.9 & - \\
Other needs & 96.0 & 4.0 & - \\
\hline
\end{tabular}

Values are percentages indicating respondents' level of agreement/disagreement with a respective survey question in the SVMI Survey (Mansouri et al. 2017)

${ }^{a}$ This is a dichotomous question with yes/no response options

Mapping Social Cohesion survey, in which $85 \%$ identified diversity as a feature of their local community (Markus 2016).

Respondents to the SVMI were further asked whether they share the apparent consensus in public discourse regarding the success of multiculturalism in Australia. The findings indicate that approximately $63 \%$ of the respondents shared this positive perception (see Table 2). This is consistent with, though lower than, findings in other national surveys, such as the Scanlon Foundation's Mapping Social Cohesion survey (2013-2016) where more than 83-86\% indicated that "multiculturalism has been good for Australia" (Markus 2016, p. 50). The Challenging Racism survey (2001-2008) reported a higher rate of acceptance of multiculturalism (88\%; Dunn and Nelson 2011). The current survey further found that this perception varied by the respondent's cultural and linguistic diversity background. Non-Anglo white Australians indicated the highest proportion of a positive view of multiculturalism (65\%), those from NESB indicated the lowest negative view (14\%) and Anglo-Australians expressed the largest negative view of multiculturalism $(18 \%)$.

Overall, these findings reflect a generally positive perception of multiculturalism among Australians, with a clear message that there is room for improvement in the everyday multicultural experience. 


\section{Understanding and Appraising Interculturalism}

Participants gave a plethora of responses to the question "What does interculturalism mean to you?" The diversity of the responses, thematically grouped into 28 categories and summarised in Fig. 2, generally indicates a lack of conceptual clarity regarding interculturalism. Indeed, a majority of the respondents (76\%) were not able to distinguish clearly between multiculturalism and interculturalism. This finding is more illuminating if one considers the responses closely. Nearly $13.5 \%$ of the respondents have provided responses somewhat close to an accepted definition of interculturalism, whereas $58.1 \%$ of respondents indicated that they were not previously aware of the concept and had no idea as to what interculturalism as a policy entailed. Additional $11 \%$ of the responses were totally unrelated to any acceptable definition of interculturalism, while just $9.8 \%$ of the respondents identified dialogue, respect, understanding, acceptance and exchange as key aspects of interculturalism. This is in contrast with $15.7 \%$ who associated respect, acceptance, coexistence and harmony with multiculturalism.

Non-response to this question (58.1\%), meaning a respondent "did not know", was "not sure" or gave a vague or no response, also suggests that, unsurprisingly, the public is less familiar with interculturalism than multiculturalism, which had a non-response rate of $19.3 \%$. While the data indicated a general lack of understanding regarding interculturalism, respondents appeared to be more aware of intercultural dialogue (ICD) (see the next subsection).

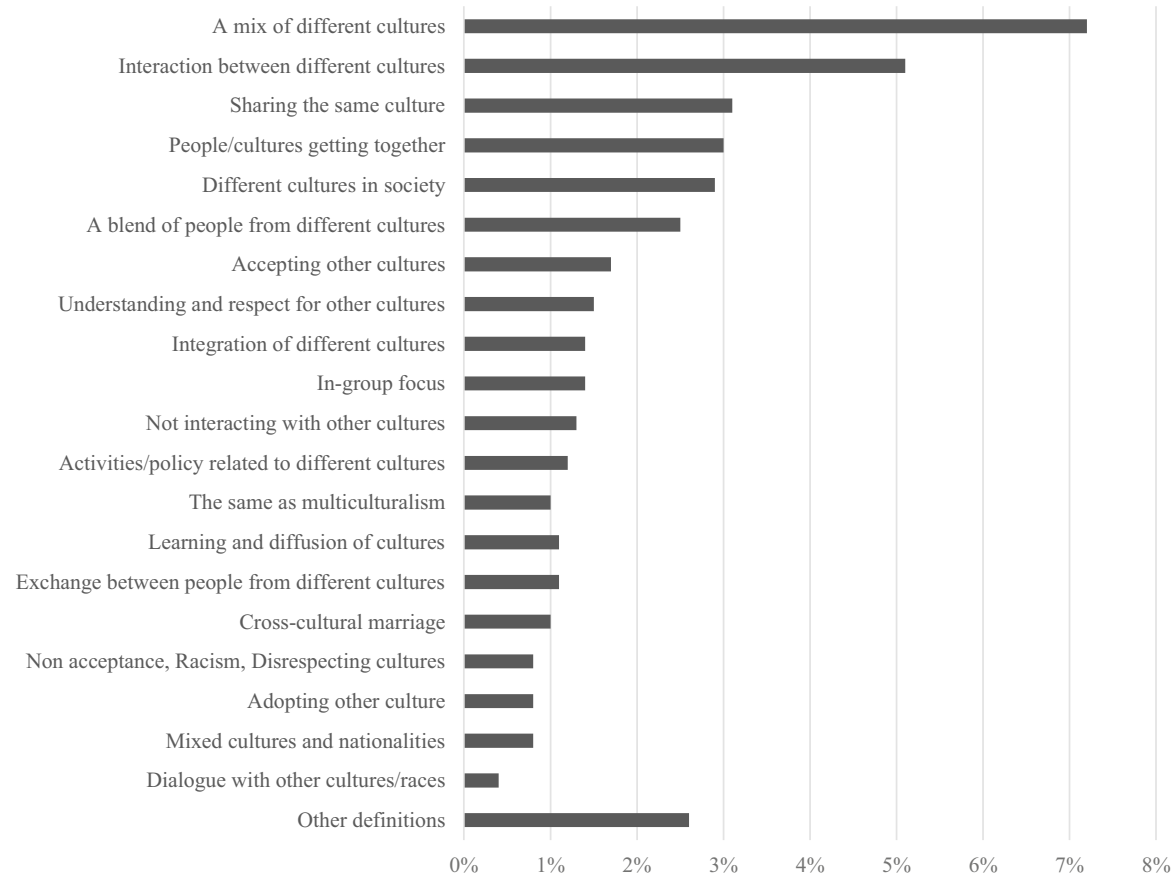

Note: Values indicate responses to the question "What does interculturalism mean to you?" Excluding "don't know", "not sure", "vague response" and an absence of response (altogether 58.1\%).

Fig. 2 Description of interculturalism by Australian respondents. Note: Values indicate responses to the question "What does interculturalism mean to you?" Excluding "don't know", "not sure", "vague response" and an absence of response (altogether 58.1\%) 


\section{Relationship Between Multiculturalism and Interculturalism}

In the literature, interculturalism has been posited as a distinct and almost superior alternative to multiculturalism, although this is not the case in the Australian context (Blair 2015; Levey 2012). To examine how the two are viewed among the general public, the SVMI asked respondents to reflect on a range of statements in relation to the two models of diversity management. The findings, reported in Fig. 3, indicate a high level of disagreement and indecision around the need to replace multiculturalism altogether with a new intercultural paradigm. Generally, the findings in relation to this question confirm the ambiguity around the meaning of interculturalism reported above.

Respondents indicated that something is needed to be done in relation to multiculturalism, though they were not sure what exactly that was. Specifically, Fig. 3 reports that nearly $30 \%$ think it is possible to replace multiculturalism with another policy tool such as interculturalism, although $38 \%$ disagree with this and an additional $32 \%$ were indifferent to its replacement. One of the most prominent criticisms levelled against multiculturalism is that it contributes to the emergence of ethnic enclaves in Western societies (Simpson 2004; Qadeer 2005; Terzano 2014). Nearly 45\% of the SVMI respondents supported this claim, with less than a third remaining neutral $(29 \%)$ or rejecting $(26 \%)$ the suggestions that the policy only promotes recognition of different ethnic groups, effectively creating ghettos.

Notwithstanding the ambiguity regarding the distinction between interculturalism and multiculturalism, some respondents thought interculturalism might be something

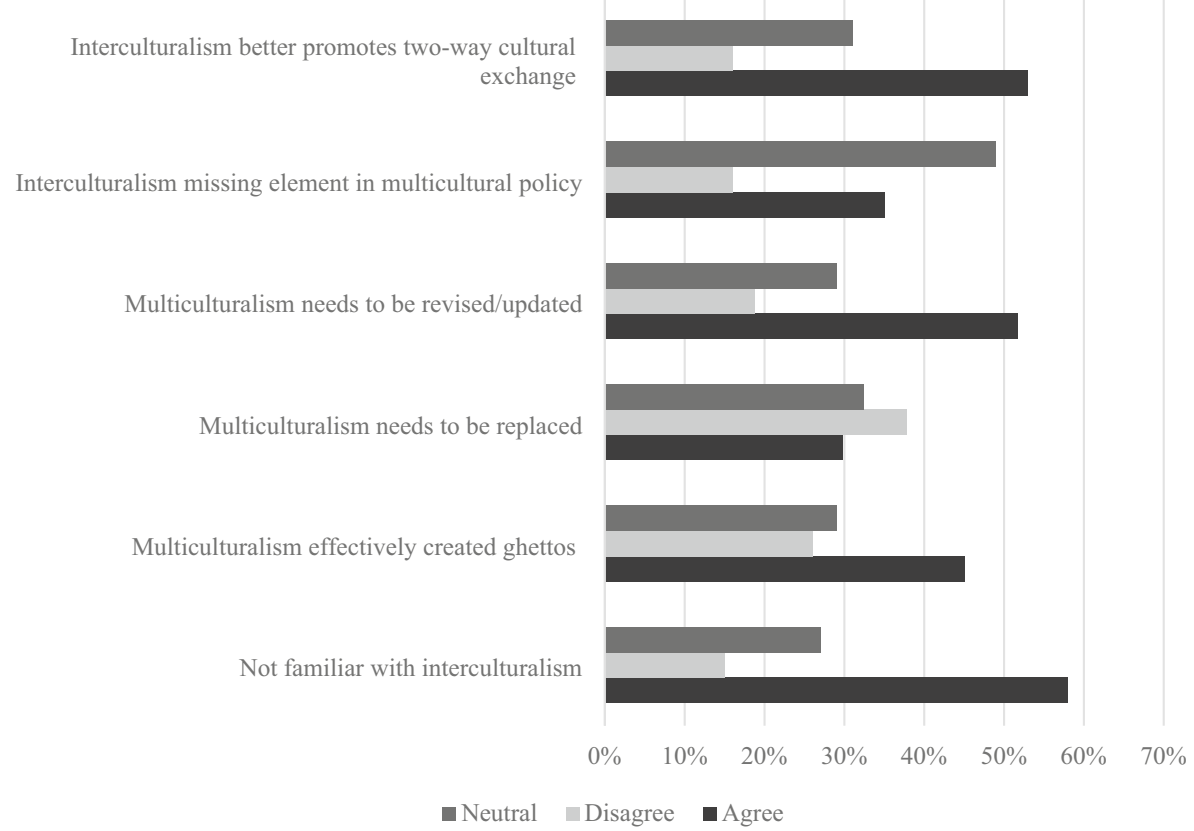

Note: The figure indicates respondents' views on interculturalism as a policy option in Australia

Fig. 3 Interculturalism in relation to multiculturalism. Note: The figure indicates respondents' views on interculturalism as a policy option in Australia 
positive. As Fig. 3 shows, respondents provided nuanced responses to the questions relating to multiculturalism and interculturalism. Nearly half of the respondents $(58 \%)$ were unsure about how to view interculturalism, 35\% thought that it may be "the missing element in current multicultural policy", roughly $38 \%$ of respondents disagreed that "interculturalism can replace multiculturalism" and 52\% of the respondents thought "multiculturalism is needed to be revised rather than replaced".

Respondents were also asked to assess whether an intercultural approach offered a better two-way relational dynamic than multiculturalism. Again, the data was inconclusive; $31 \%$ remained neutral, while $53 \%$ agreed that interculturalism, in contrast to multiculturalism, does encourage a more dialogic (two-way) cultural exchange.

Further analysis of public attitudes towards multiculturalism and interculturalism indicates slight variation by age group, with no major variation by education. A majority of participants (55\%) across age groups think that multiculturalism encourages interaction, dialogue and exchange while there is a general concern that multiculturalism may create ghettos (44\%). This is slightly higher among older participants (aged 65+: $54 \%$ ) who also think that multiculturalism needs to be replaced (34\%). While all age groups showed a general lack of clarity around the meaning of interculturalism, younger participants $(<35$ years) are more likely to think it cannot replace multiculturalism $(42 \%)$. Unlike age, there seems to be no major distinction in the level of support for multiculturalism and interculturalism by participant level of education. However, those who finished year 12 or had certificate/diploma were more likely to indicate multiculturalism needs replacement, while those with bachelor degree and above more indicated that interculturalism unlike multiculturalism promotes a two-way intergroup exchange.

\section{Reinvigorating Multiculturalism Through Intercultural Dialogue}

To assess public opinion on whether multiculturalism needed an intercultural intervention, respondents were prompted to comment on their knowledge of ICD and how effective they think existing multicultural policies are for encouraging intercultural interaction, dialogue and exchange. In addition, they were asked to reflect on some of the key challenges they thought still exist for developing and conducting successful ICD.

Overall, respondents appeared to have general awareness of what ICD entailed. Although most of them (76\%; see Fig. 2) were unable to articulate an accurate definition of interculturalism, more than half $(62 \%)$ correctly identified the key aspects of ICD when presented with multiple choices (Fig. 4). They distinctly identified ethnolinguistic and cultural backgrounds as essential constituents of ICD. However, more than half of the respondents understood ICD as a dialogue between people with different levels of educational attainment. Likewise, nearly half of all respondents understood ICD as involving some kind of dialogue between different states, an indication, perhaps, of confusing the word "intercultural" with "international".

The literature indicates that individual intercultural knowledge and competence are essential ingredients for the conduct of a successful ICD (Council of Europe 2008; Odora-Hopper 2007). In the SVMI, respondents were also asked to reflect on what they thought ICD needed to produce a positive impact. As reported in Table 2, respondents highlighted individual acceptance and engagement as the key ingredients of an effective ICD, followed by inclusivity and locality. Nearly $64 \%$ identified people-to-people 
What is central to intercultural dialogue

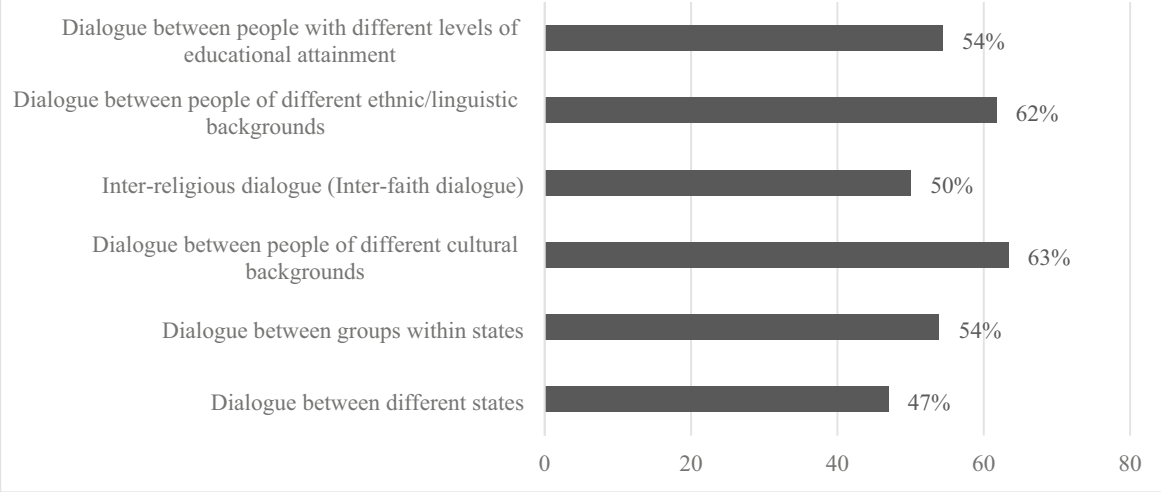

Note: Responses to the question 'What is central to intercultural dialogue?'

Fig. 4 Public understanding of intercultural dialogue in Australia. Note: Responses to the question "What is central to intercultural dialogue?"

contact as an essential factor, with more than $63 \%$ pointing out the need for inclusive participation from all - and not just minoritised-groups. More than half of the respondents (58\%) emphasised the importance of local support rather than a top-down (government directives) approach as essential for a successful ICD.

Finally, in relation to the practical implementation of ICD, respondents highlighted resourcing and training as the key challenges in Australia (61\%), followed by political leadership (58\%). Fewer than half cited the ambiguity of ICD policy articulation as a challenge and just $7 \%$ mentioned additional challenges. These included the lack of tolerance and acceptance of difference, intercultural prejudice and racism against some minority groups and the lack of understanding of and an unwillingness for intercultural interaction, the media and language barriers. While intolerance, prejudice and racism have been identified as challenges to ICD, ICD could also be used as a potential antiracism tool (Elias 2017; Bello 2017).

\section{Discussion}

Drawing on Australian online national survey data, this paper examined public perceptions and understanding of multiculturalism and interculturalism. The concepts have at times been posited in the literature as two different approaches to managing diversity and have often been depicted as mutually exclusive policy paradigms (Cantle 2012; Meer and Modood 2012). This paper sought to examine empirically the extent to which there is public understanding of and support for these two diversity governance approaches. Multiculturalism has been an integral part of Australian national identity for the past four decades (Lopez 2000), which may explain why survey respondents overall had a more cognisant view of it in comparison with interculturalism. However, growing criticism towards perceived lack of political leadership regarding the future of multiculturalism has been detected within the general public, which is supported by the overall findings of this study. 
Both as a concept and as a policy, multiculturalism has challenged strongly held traditional views about national identity, social inclusion and race relations (Mansouri 2015; Forrest and Dunn 2006). While multiculturalism was widely accepted in public policy as an appropriate approach for Australia's changing demographics, public attitudes have varied overtime. Indeed, a 1988 survey reported ambivalent attitudes, and found that Australians thought that migrants should try hard to assimilate to "the Australian way of life" (Ho 1990, p. 202). Some criticisms alleged that multicultural policies reinforced and entrenched cultural difference and favoured minority ethnic groups over other Australians. However, such attitudes tended to associate multiculturalism with immigration policies rather than with inclusive approaches to managing growing diversity.

There was a brief decline in public support of multiculturalism during the second half of the 1990s when anti-immigration sentiments gained traction, leading to the election of a conservative Liberal government and the rise of the right wing One Nation Party (Ang and Stratton 1998; Forrest and Dunn 2006). However, public attitudes have improved overtime, with stronger public support in recent years (Markus 2016).

Indeed, as this study's findings show, a multicultural society with increasing ethnic, religious and cultural diversity is a fundamental characteristic of Australia's identity. Certainly, this is consistent with other studies that have consistently reported a similar consensus regarding diversity being intertwined with Australian national identity. A good case in point here is the Mapping Social Cohesion survey, in which $85 \%$ of respondents identified diversity as a positive feature of their local community (Markus 2017). This suggests that the diversity that is visible in everyday lived experience may have contributed to our respondents' recognition of the country's multicultural identity.

Given this strong level of public support (Dandy and Pe-Pua 2010), multiculturalism will remain an important policy tool in Australia, even if it has come under criticism elsewhere, including in the UK, France and Germany (Joppke 2004; Kymlicka 2012; Meer et al. 2015).

However, as our findings show, the attitude towards and level of support for multiculturalism are likely to vary depending on the ethnic background and level of intercultural interaction of respondents (Dandy and Pe-Pua 2010; García-Faroldi 2017). Indeed, an awareness of multiculturalism and cultural diversity can often lead to a positive assessment of its policy outcomes. This is indicated in the general public acceptance that Australia is a successful multicultural society (Ho and Alcorso 2004; Markus 2017), with people from migrant backgrounds more likely to recognise the success of multiculturalism for a culturally diverse Australia.

In contrast to this view of a multicultural Australia, there remains an enduring belief among a significant minority in the mono-cultural basis of the Australian national identity, which also might explain the relatively lower level of support for multiculturalism among Anglo-Celtic Australians. The mono-cultural assumption within Australian society privileges the Anglo-Celtic above all other cultures, including the millennia-old Indigenous cultures. It is this contested notion of how Australian identity should be viewed that features frequently in criticisms of multicultural policies (Mansouri et al. 2017). For example, during the John Howard and Tony Abbott conservative governments, Australian multiculturalism was intensely challenged with the proposed "citizenship test" and failed weakening of "anti-vilification" provisions within the Racial Discrimination Act 1975 (Levey 2018b). Both of these polarising issues may have also contributed to the exaggerated negative public perception of multiculturalism. 
Furthermore, the broader critical literature on multiculturalism has often focused on its perceived "corrosive" effect on social cohesion through furthering self-segregation and engendering ethnic enclaves (Qadeer 2005; Simpson 2004; Terzano 2014; Vertovec and Wessendorf 2010). However, as the findings of the present study show, less than half of our respondents supported this proposition, with a majority still holding a strong belief in the positive role of multiculturalism, even if they agree some intercultural recalibration might be needed. This contrasts with Europe where such policy shifts are already taking place in more radical terms, with a move towards a substitutive intercultural policy paradigm (Cantle 2012) that is proposed as a panacea for the perceived migration problem.

Although interculturalism emerged more than a decade ago as the basis for a diversity policy paradigm in Europe and North America, in Australia there remains little public awareness of its precise meanings or its possible translation into the policy domain (Levey 2018b). The term itself has only recently entered into Australian public discourse and has yet to penetrate the wider public policy debate (Ballantyne and Malhi 2017; Levey 2018b). Therefore, it is not surprising that most of the survey respondents exhibited a lack of familiarity with what it meant exactly and how it can be differentiated from multiculturalism. To some extent, this seems to corroborate the "difference without distinction" argument within the multiculturalism-interculturalism debate.

Our research findings indicate greater awareness and stronger support for multiculturalism, with some recognition that it needs to adapt and address current social issues. Australians generally express positive attitudes towards multiculturalism while they see rooms for improvement through strategic policy innovation. The study findings indicate a general lack of clarity regarding interculturalism and its differentiation from multiculturalism although those indicating familiarity with the concept regard it as a potential missing link for a proactive and deliberative engagement.

Although intercultural studies in general have expanded over the last two decades, as the findings above have shown, the intercultural paradigm is yet to become a feature of public policy debates. Indeed, the ongoing polarised contestation within the intercultural-multicultural debate has added to the confusion around public understanding of the very concept itself. Thus, this study's findings provide much needed contextual analysis on the public understanding and potential uptake of intercultural policies (Mansouri 2017; Zapata-Barrero 2013). To this end, multicultural policies that have had historically an overarching goal of engendering social inclusion and societal harmony are currently in need of some form of recalibration in order to be able to respond to the new realities of hyper-diverse societies and their shifting geopolitical landscapes. Yet, the intercultural framework that can potentially contribute to such recalibration, remains in need more conceptual clarity and precision in order to offer a platform for policy complementarity around diversity agenda.

Reflecting its unique philosophical assumptions, interculturalism has the capacity to offer meaningful opportunities and practical tools for cross-cultural engagement. Its utility supposedly lies in its focus on transformative intercultural engagement with its distinctively individual focus, bottom-up initiatives and communitydriven deliberative approach. In Australia, interculturalism has operated to some extent in specific sectors, particularly in education and local governance, with several city council initiatives also adopting the intercultural approach to achieve social cohesion (Blair 2015; Walton et al. 2013). 
Yet the effectiveness of an intercultural approach ultimately depends on many factors, including, as identified by some respondents in this study, individual commitment, mainstream society engagement and a grassroots emphasis. As participants in this study indicated, sustainable funding, political leadership and clarity around policy articulation remain critical factors for the successful implementation of any policy orientation. An intercultural framework that encourages bi-directional and multidirectional cross-cultural engagement can respond to the challenges of super-diversity (Vertovec 2007). The success of such a framework requires a proactive macro policy plan with clearly defined strategies, committed resources and predefined targets. This is where multiculturalism comes in as providing the broader structural enabling conditions. There is emerging conceptual work in the literature (Mansouri and Modood 2020) that postulates a necessary complementarity between multiculturalism and interculturalism, as two pro-diversity concepts, for a genuine reinvigoration of the overall diversity agenda at a time where there is a resurgence in ultra-nationalist, xenophobic and white supremacists ideologies and groups. The Australian case study in this respect differs from the situation in the UK, France and Germany where support for multiculturalism has been decreasing publicly and particularly within political discourse (Meer et al. 2015; Cantle 2012). This is especially the case in France and Germany where the declared "utter failure" of multiculturalism does not actually reflect factually the existence of proactive policies and ideologies supporting and enacting multiculturalism as is the case in Australia and Canada, for example.

\section{Limitations}

The cross-sectional nature of the survey is the main limitation of this study, as longitudinal studies can allow for better indication of changes in public attitudes over time. Non-probability sample has also limitations in terms of representativeness, while this has been considered during recruitment. To compensate for the imbalance in the survey due to the under-representation of certain groups in the population, weights were computed using census data for education, as recommended in Johnson (2008).

\section{Conclusion}

This paper examines public attitudes towards multiculturalism and interculturalism as two distinct yet connected approaches to the migration and diversity agenda. Recent global intercultural initiatives (e.g. Council of Europe and UNESCO) have signalled a possible movement towards an intercultural paradigm. However, in the Australian context, intercultural interaction has operated largely and successfully within a broader multicultural framework. Reflective of this unique empirical reality, the findings of this study indicate strong support among respondents for Australian multiculturalism, despite some recognition that it needs some revision to adapt to be more inclusive and socially engaging. A reinvigoration of Australian multiculturalism could be best pursued if conditions are created that ensure strong political leadership, clear communication with the public and sustainable resourcing at different levels of government.

Furthermore, and given the broad support for multiculturalism in Australia reported in this paper and numerous other studies, employing intercultural strategies must be 
viewed as additive to rather than substitutive of multiculturalism that still enjoyed significant accrued socio-political capital. Australia's multicultural success cannot be taken for granted given the rising level of security concerns and the changing nature of the international geopolitical landscape. The endurance of a successful multicultural approach requires the incorporation of more proactive initiatives that can engender meaningful engagement between individuals from minority and majority groups interacting deliberatively at the grassroots level. This is precisely the promise of interculturalism, which can provide optimal conduits for the engagement and inclusion of all, and the acceptance of living with difference. More critically, interculturalism remains an essential ingredient for individuals to embark on the reflexive critical process of examining one's own cultural biases, value orientations and knowledge base, particularly, as these shape one's perception of different others.

However, interculturalism needs to show convincingly its intrinsic value as a micropolicy tool that can augment the macro-ideology of multiculturalism as twin components of diversity agenda. Such a complementarity approach can ensure super-diversity will have a positive impact on issues pertaining to national belonging, local engagement and global citizenship (Kymlicka and Norman 2000; Young 2000).

Open Access This article is licensed under a Creative Commons Attribution 4.0 International License, which permits use, sharing, adaptation, distribution and reproduction in any medium or format, as long as you give appropriate credit to the original author(s) and the source, provide a link to the Creative Commons licence, and indicate if changes were made. The images or other third party material in this article are included in the article's Creative Commons licence, unless indicated otherwise in a credit line to the material. If material is not included in the article's Creative Commons licence and your intended use is not permitted by statutory regulation or exceeds the permitted use, you will need to obtain permission directly from the copyright holder. To view a copy of this licence, visit http://creativecommons.org/licenses/by/4.0/.

\section{References}

Abdallah-Pretceille, M. (2006). Interculturalism as a paradigm for thinking about diversity. Intercultural Education, 17(5), 475-483.

Ang, I., \& Stratton, J. (1998). Multiculturalism in crisis: the new politics of race and national identity in Australia. TOPIA: Canadian Journal of Cultural Studies, 2, 22-41.

Arsaratnam, L. A. (2013). A review of articles on multiculturalism in 35 years of IJIR. International Journal of Intercultural Relations, 37(6), 676-685.

Australian Bureau of Statistics. (2017). Census of Population and Housing 2016, QuickStats. Available at http://www.censusdata.abs.gov.au/census_services/getproduct/census/2016/quickstat/036. Accessed 20 July 2017.

Ballantyne, G., and Malhi, A. (2017). Interculturalism: how diverse societies can do better than passive tolerance. The Conversation. 21 March.

Banting, K., \& Kymlicka, W. (2013). Is there really a retreat from multiculturalism policies? New evidence from the multiculturalism policy index. Comparative European Politics, 11(5), 577-598.

Barry, B. (2001). Muddles of multiculturalism. New Left Review, 8, 49-71.

Bello, V. (2017). Interculturalism as a new framework to reduce prejudice in times of crisis in European countries. International Migration, 55(2), 23-38.

Blair, K. (2015). Young adults' attitudes towards multiculturalism in Australia: Tensions between the multicultural state and the intercultural citizen. Journal of Intercultural Studies, 36(4), 431-449.

Bouchard, G., \& Taylor, C. (2008). Building the future: a time for reconciliation. In T. Das Gupta, C. E. James, C. Andersen, G. Galabuzi, \& R. C. A. Maaka (Eds.), Race and Racialization, 2E: Essential Readings (pp. 302-317). Toronto: Canadian Scholars.

Cantle, T. (2012). Interculturalism: the new era of cohesion and diversity. London: Palgrave Macmillan. 
Castles, S. (2002). Migration and community formation under conditions of globalization. International Migration Review, 36(4), 1143-1168.

Castles, S. \& Miller, M. J. (2003). The age of migration: International population movements in the modern world, 2nd ed. London: Palgrave.

Colic-Peisker, V. (2011). A new era in Australian multiculturalism? From working-class 'ethnics' to a 'multicultural middle-class'. International Migration Review, 45(3), 562-587.

Council of Europe. (2008). White paper on intercultural dialogue: 'Living together as equals in dignity'. Strasbourg Cedex: Council of Europe.

Dandy, J., \& Pe-Pua, R. (2010). Attitudes to multiculturalism, immigration and cultural diversity: Comparison of dominant and non-dominant groups in three Australian states. International Journal of Intercultural Relations, 34(1), 34-46.

Dei, G. J. S. (2011). Defense of official multiculturalism and recognition of the necessity of critical antiracism. Canadian Issues, Spring, 2011, 15-19.

Delafenetre, D. G. (1997). Interculturalism, multiracialism and transculturalism: Australian and Canadian experiences in the 1990s. Nationalism and Ethnic Politics, 3(1), 89-110.

Delany-Barmann, G. (2010). Teacher education reform and subaltern voices: From Política to Práctica in Bolivia. Journal of Language, Identity, and Education, 9(3), 180-202.

Dunn, K. M., \& Nelson, J. K. (2011). Challenging the public denial of racism for a deeper multiculturalism. Journal of Intercultural Studies, 32(6), 587-602.

Elias, A. (2017). Racism, anti-racism and intercultural dialogue. In F. Mansouri (Ed.), Interculturalism at the crossroads: Comparative perspectives on concepts, policies and practices (pp. 257-276). Paris: UNESCO Publishing.

Elias, A., \& Mansouri, F. (2020). A systematic review of studies on interculturalism and intercultural dialogue. Journal of Intercultural Studies, 41(4), 490-523.

Forrest, J., \& Dunn, K. (2006). 'Core' culture hegemony and multiculturalism. Ethnicities, 6(2), 203-230.

Freeman, G. P. (2004). Immigrant incorporation in Western democracies. International Migration Review, 38(3), 945-969.

García-Faroldi, L. (2017). Determinants of attitudes towards immigration: Testing the influence of interculturalism, group threat theory and national contexts in time of crisis. International Migration, $55(2), 10-22$.

Hassan, R., \& Martin, B. (2015). Islamophobia, social distance and fear of terrorism in Australia. Australia: A preliminary report, University of South Australia.

Ho, R. (1990). Multiculturalism in Australia: a survey of attitudes. Human Relations, 43(3), 259-272.

Ho, C., \& Alcorso, C. (2004). Migrants and employment challenging the success story. Journal of Sociology, 40(3), 237-259.

Johnson, D. R. (2008). Using weight in the analysis of survey data. Population Research Institute. The Pennsylvania State University.

Joppke, C. (1996). Multiculturalism and immigration: A comparison of the United States, Germany, and Great Britain. Theory and society, 25(4), 449-500.

Joppke, C. (2004). The retreat of multiculturalism in the liberal state: theory and policy. The British Journal of Sociology, 55(2), 237-257.

Joppke, C. (2017). Civic integration in Western Europe: three debates. West European Politics, 40(6), 11531176.

Jupp, J. (2002). From white Australia to Woomera: The story of Australian immigration. Cambridge: Cambridge University Press.

Koleth, E. (2010). Multiculturalism: a review of Australian policy statements and recent debates in Australia and overseas. Research Paper No. 6, 2010-11, Parliament of Australia.

Kymlicka, W. (1995). Multicultural citizenship: A liberal theory of minority rights. Oxford: Clarendon Press.

Kymlicka, W. (2012). Multiculturalism: Success, Failure, and the Future. Washington: Migration Policy Institute.

Kymlicka, W., \& Norman, W. J. (Eds.). (2000). Citizenship in diverse societies. Oxford: Oxford University Press.

Levey, G. B. (2012). Interculturalism vs. multiculturalism: a distinction without a difference? Journal of Intercultural Studies, 33(2), 217-224.

Levey, G. B. (2018a). The Bristol school of Multiculturalism. Ethnicities. https://doi.org/10.1177/ 1468796818787413.

Levey, G. B. (2018b). Does multiculturalism inhibit intercultural dialogue? Evidence from the Antipodes. Journal of Citizenship and Globalisation Studies. https://doi.org/10.1515/jcgs-2018-0002. 
Levrau, F. (2018). Introduction: Mapping the multiculturalism-interculturalism debate. Comparative Migration Studies., 6(1), 13.

Liddicoat, A. J. (2009). Evolving ideologies of the intercultural in Australian multicultural and language education policy. Journal of Multilingual and Multicultural Development, 30(3), 189-203.

Lopez, M. (2000). The origins of multiculturalism in Australian politics 1945-1975. Melbourne: Melbourne University Press.

Mansouri, F. (2015). Cultural, religious and political contestations: the Multicultural challenge. Cham: Springer.

Mansouri, F. (2017). Introduction: the conceptual conundrum around intercultural dialogue. In F. Mansouri (Ed.), Interculturalism at the crossroads: Comparative perspectives on concepts, policies and practices (pp. 13-22). Paris: UNESCO Publishing.

Mansouri, F., \& Modood, T. (2020). The complementarity of multiculturalism and interculturalism: Theory backed by Australian evidence. Ethnic and Racial Studies, 1-20. https://doi.org/10.1080/01419870.2020.1713391.

Mansouri, F., Elias, A., \& Sweid, R. (2017). The doing diversity project: Revitalising multiculturalism through an intercultural lens and deliberative interventions. Melbourne: Deakin University.

Markus, A. (2016). Mapping Social Cohesion: The Scanlon Foundation surveys 2016. Melbourne: Monash University.

Markus, A. (2017). Mapping Social Cohesion: The Scanlon Foundation surveys 2017. Melbourne: Monash University.

May, S., \& Sleeter, C. E. (2010). Introduction. In S. May \& C. Sleeter (Eds.), Critical multiculturalism: Theory and praxis (pp. 33-48). New York: Routledge.

Meer, N., \& Modood, T. (2012). How does interculturalism contrast with multiculturalism? Journal of Intercultural Studies, 33(2), 175-196.

Meer, N., Mouritsen, P., Faas, D., \& de Witte, N. (2015). Examining 'postmulticultural' and civic turns in the Netherlands, Britain, Germany, and Denmark. The American Behavioral Scientist, 59(6), 702-726.

Meer, N., Modood, T., \& Zapata-Barrero, R. (2016). Multiculturalism and interculturalism: Debating the dividing lines. Edinburgh: Edinburgh University Press.

Michalski, K. (Ed.). (2006). Religion in the new Europe (Vol. 2). Budapest: Central European University Press.

Modood, T. (2007). Multiculturalism: a civic idea. Cambridge: Polity Press.

Modood, T. (2011). Multiculturalism, ethnicity and integration: struggling with confusions. In H. Mahamdallie (Ed.), Defending Multiculturalism: A Guide for the Movement (pp. 61-76). London: Bookmarks.

Modood, T. (2017). Must interculturalists misrepresent multiculturalism? Comparative Migration Studies, 5(1), 15.

Modood, T., \& Meer, N. (2012). Interculturalism, multiculturalism or both? Political Insight, 3(1), 30-33.

Odora-Hopper, A. (2007). Investing in cultural diversity and intercultural dialogue. Paris: UNESCO World Report.

Parekh, B. (2000). Rethinking multiculturalism: Cultural diversity and political theory. London: Palgrave.

Però, D. (2013). Migrants, cohesion and the cultural politics of the state: Critical perspectives on the management of diversity. Journal of Ethnic and Migration Studies, 39(8), 1241-1259.

Qadeer, M. A. (2005). Ethnic segregation in a multicultural city. In Varady DP (ed) Desegregating the city: Ghettos, enclaves and inequality (pp. 49-61). Albany: State University of New York Press.

Rodríguez-García, D. (2010). Beyond assimilation and multiculturalism: a critical review of the debate on managing diversity. Journal of International Migration and Integration, 11, 251-271.

Simpson, L. (2004). Statistics of racial segregation: measures, evidence and policy. Urban Studies, 41(3), 661-681.

Solano-Campos, A. T. (2013). Bringing Latin America's 'Interculturalidad' into the conversation. Journal of Intercultural Studies, 34(5), 620-630. https://doi.org/10.1080/07256868.2013.807231.

Syed, J., \& Kramar, R. (2009). What is the Australian model for managing cultural diversity? Personnel Review, 39(1), 96-115.

Taylor, C. (1994). Multiculturalism. Princeton: Princeton University Press.

Terzano, K. (2014). Commodification of transitioning ethnic enclaves. Behavioural Sciences, 4(4), 341-351.

Triandafyllidou, A. (Ed.). (2012). European multiculturalisms: Cultural, religious and ethnic challenges. Edinburgh: Edinburgh University Press.

Vertovec, S. (2007). Super-diversity and its implications. Ethnic and Racial Studies, 30(6), 1024-1054.

Vertovec, S. (2010). Towards post-multiculturalism? Changing communities, conditions and contexts of diversity. International Social Science Journal, 61(199), 83-95.

Vertovec, S., \& Wessendorf, S. (Eds.). (2010). The Multiculturalism Backlash: European Discourse, Policies and Practices. London: Routledge.

Walton, J., Priest, N., \& Paradies, Y. (2013). Identifying and developing effective approaches to foster intercultural understanding in schools. Intercultural Education, 24(3), 181-194.

Young, I. M. (2000). Inclusion and democracy. Oxford: Oxford University Press.

Zapata-Barrero, R. (2013). The three strands of intercultural polities: a comprehensive view. GRITIM-UPF Working Paper Series, No. 17, Universitat Pompeu Fabra, Spain.

Zapata-Barrero, R. (Ed.). (2015). Interculturalism in cities: Concept, policy and implementation. Cheltenham: Edward Elgar Publishing. 
Zapata-Barrero, R. (2017). Interculturalism in the post-multicultural debate: a defence. Comparative Migration Studies, 5, 14. https://doi.org/10.1186/s40878-017-0057-z.

Zapata-Barrero, R. (2019). Intercultural citizenship in the post-multicultural era. London: Sage Publications.

Publisher's Note Springer Nature remains neutral with regard to jurisdictional claims in published maps and institutional affiliations. 